\title{
Methods of Teaching English and the Teacher
}

\author{
Ervin Balla \\ PhD Candidate \\ University of Tirana, Albania \\ Email: Ervin_balla@yahoo.com
}

\section{Doi:10.5901/ajis.2014.v3n4p89}

\begin{abstract}
The methods used to teach the students should have an impact in their motivation. If they find it terribly boring or frustrating they will de-motivate quickly, while if they like the method they will find it very motivating. Their motivation will influence their learning the foreign language, nevertheless its a little difficult to define a good method, but what we know for sure is the fact that the students can lose interest quickly in a given method, and the belief of the students in the method is mainly in the hand of the most important factor that influences the students inner motivation, the teacher.
\end{abstract}

Keywords: Students, methodology, teacher, motivation

\section{How Important is the Teacher to the Students}

According to the surveys the teacher remains always the safest source for the acceptability of the methods to the students. He remains the safest support that the students could find themselves in the methods used, to make them more comprehensive and adjustable for them. It is true that the recent texts and methods are more interesting than the old ones, but an experienced and interested teacher in the subject can attract the attention of the students and make the class very interesting for his students. A good teacher brings extra materials to the class; he brings different experiences expressed in English. The students will feel motivated and interested in the class and the cooperation between them will increase having a better feedback, so in general we say that no matter how complete and updated is the method used it can never be totally decisive for the progress of the class, because as we said a great and important role also plays the mediator, which in this case is the teacher. What should also be taken into consideration is the adjustability of the student with the method. An intermediate student cannot waste his time with an elementary method. Also a beginner student cannot work with an advanced method. At the position of the teacher of English, we will have to stop a little longer, because many factors are closely connected with the process of teaching and learning. It is made very evident from different scholars that the events and experiences in their personal life are bounded to their professional role (Ball and Godson 1985). Complex problems in their personal life can be connected to the performance and the results in his work. For this issue (Heargraves 1992) commenting a text of Huberman over the professional career of the teachers stressed:

"Teachers do not have simply a Job. They have personal and professional life also, so to understand the teacher means to understand the person teacher is"

(Woods 1997) also argues that "teaching is a question of values". People teach because they believe in something. They have an image of the "good society"

To build the profile of two teachers of English, to those with a low level of pleasure for the work and to those with a high level of pleasure for the work, the results show that the first teachers can be differentiated by the teachers with a high pleasure of work by the perception that they have for the work and by a number of different demographic features. Surprisingly Hall saw that the teachers that were planning to quit their profession reported less pleasure regarding their work. Later (Smithers and Robinson 2003) investigated the factors that influence in the decisions of the teachers to quit their profession. This study identified five key factors that teachers wanted to quit their profession:

1. Load of work

2. New challenges

3. School context

4. Salary 


\section{Personal circumstances}

All these factors played a decisive role in the personal preferences of the teachers to abandon their profession. However the same factors expressed positively will influence positively to the teachers to motivate them and to urge them to achieve high professional results in his work, there are five fields in which the teachers express their abilities (Westwood 1995) these fields include:

1. presentation and explanation

2. asking students during class

3. giving feedback

4. training and adjustment with the new fields of education

5. adapting of different instructions and their implementation

\section{Presentation and Explanation}

The presentation of the information for the students, giving the explanation and answering to their questions are three from the main activities in which the teachers are committed (Eugene and Kauchak 2004). Being clear during the explanation is very frequently the key feature of the best teachers. Expert teachers have high results are reported to implement the below features in their teaching (Bush and Kincer 1993)

- Efficient presentation of the new assignments

- Clear guidelines

- A greater variation of the ways of explanation of the topics

Effective teaching in class like the formal teaching asks for clearness during the explanation. Weak explanation make the students confuse and creates problem in the teaching. This lack of clarity can be because of the failure of effective communication in the level of the terminology that the student may dispose, use of complex terminology, not enough examples where the student may rely, not enough visual supporting materials, presentation of many materials at the same time, not making clear the relationships, and the disability to control the understanding. (Sotto 1994) believes that a teacher is clear when the guidelines and explanation is based in the following factors:

- Teacher knows very well the subject

- The point of view of a student that studies the subject for the first time

- The identification of the main topics to be stressed during the class

- Explanation in simple terms

The explanation should not be one side process. A good explanation asks for questions addressed to the students, to make sure that everything that is stated has sense and the students should be urged to make questions to the teacher after the explanation An important area in the development of the teacher's relationship with the students' achievement is mediator factor in the effectiveness of the teacher (Ashton and Web 1986), the belief of the teacher that they may have a positive effect in the success of the teacher. In a way that could teach effectively a teacher not only should feel comfortable psychologically and emotionally, but they should feel that their work is bringing positive changes to their students. Also the inner motivation plays an important role in the process of teaching. The students that see a motivation in their teachers work are more productive in general than those who do not see this urge. If the students like or not their teacher it is not very important, however two teachers using the same method may have different results. So how can we evaluate the qualities of the teacher in giving the inner motivation? In a study, Denis Girard (Denis Girard 1970) tried to give an answer to this question. One thousand students from twelve up to seventeen years were asked to list the qualities of the teacher according to their preferences. They have to 1 - very important, 10 - less important. They listed as follows:

1. Teacher makes an interesting course

2. Teacher makes a good pronunciation of the words

3. Teacher explains clearly

4. He speaks English clearly

5. He shows the same interest to the students

6. He makes the students participating

7. He shows great patience

8. He insists in the spoken language

9. He makes the students work

10. He uses an audio method during his explanation 
Interestingly the key point of the study came in the tenth place. The students were more concerned that the classes could be more interesting, and three out of ten qualities 5,6,7 have to do with the relationship between the teacher and the students. Students were asked to list some qualities that they thought were important. And the most important were:

- Teacher shows sympathy for his students

- He is fair with everyone

- He conveys trust

Another formal study of Westwood (Westwood 1995) asked students and teachers their opinion of a good teacher. (All the teachers belonged to English language). About two thirds of the answers were the relationship of the teachers with the students and the personality of the teachers. They also mentioned the need of the teachers to motivate the students with interesting classes, and only some of them wanted the teachers to be more prepared and also be the persons where they could trust.

From a study performed with 180 students from the first year at the University "Aleksander Moisiu" of Durres I reached the following conclusions:

1. The teachers owes very well the subject

2. The teacher explains clearly

3. He speaks good English

4. He makes an interesting course

From the analysis of the studies it is noted that the students appreciate the professional and pedagogical preparation of the teachers. As grownups they evaluate the fact that the teacher respects them for what they are and for what they do. We can make some generalisations about this. For i.e the personality of the teacher matters a lot (and this is the most difficult part to be trained). But beyond this it is clear that the teachers need to do everything that is possible to create a good relationship with their students, partly this comes by making interesting and motivating classes, and partly comes from treating the students equally

\section{Methods of Teaching}

The methods of teaching used to teach students should be effective for the students. If they find it terribly boring they will be de-motivated, but if they trust the method they will find it motivating and interesting, but maybe this is the most difficult thing for all. We said earlier that the motivated students will be successful regardless the method used. It is true also that, different students are more or less sympathising to any special method, this also relying into their expectation. Teachers can recognise easily the students that have not learned enough grammar or enough conversation (Farrell and Jacobs 1997). However with all the continuous attempts, there has never been any research that could indicate exactly which is the most accurate method, but what we know exactly is the fact that students may loose interest in the method used or be de-motivated. The belief in the method is in the hand of the most important factor, the influences in the inner motivation that is the teacher. No matter how good is a contemporary method, it cannot be considered complete for the class, because as we said an important role is played by the teacher. What should be kept in mind is the adjustability of the level of students with the method, an intermediate student should not waste his time with a pre-intermediate method or beginner method, as it happens very frequently in our universities, but in this case we should divide them into smaller groups according to their level of knowledge. Very frequently the advanced students with the inappropriate method start to lose interest in the class and with the passing of time start to make absences with the excuse "that he is not learning anything new" or "I know all these things". The same happens with the beginner students if the method is more advanced for them. They start to justify that the method is very difficult and they don't understand anything starting not to show off in the class, both these cases show a clear lack of interest from the students, bringing into failure of learning. A better match of the student with the method would lead into a greater interest of the student for the English language, seeing it not only as a tool to be "liked by the teacher" or to "get a high grade", but as powerful weapon to learn the English language

Among many methods of teaching the placement of students into groups to work together is considered by most as a very good strategy to be used. Effective teachers implement the work in groups as a key method to learn the language (Westwood 2008). The work in groups not only increases the participation of the students but also encourages the development of social abilities, and independence too. The students that work together, share their ideas together, they also learn from other, making the process more effective.

When we make the students work in groups it is important to take into consideration these things:

1. The size of the group should be important. It is better if we start with small groups of students made up by two 
persons

2. It is better do the same assignment at the same time, to manage the time more effectively

3. It is not important only to create groups and put the students to work. The groups of work should be taught to cooperate. They should also share ideas and offer help each other

4. The solving of the assignments of the group is very important. Works ask for cooperation and it should be well planned and relied in the abilities of the students.

5. Teacher should monitor very closely the activities of the group interfere when he finds necessary giving suggestions, praise the good work also

6. Members of the group of work should stick together, but they also should have the space required to work the materials without obstacle each other

7. The groups of work should be used by the students to learn different abilities (dialogues conversations, every day conversation in English, etc)

\section{Conclusions}

As we mentioned in this article the methods of teaching English language are numerous and the recent ones are really well conceived and very handy to learn the language, but what matters most in the long process of learning the English language is the teacher. A good and motivated teacher is very frequently what makes the difference. Also the methods of teaching are really very helpful in this process but one of the most efficient which should be used is the division in groups. Those and how are divided the groups are mentioned in my article

\section{References}

Heargraves A. (1992) "Teacher development and educational change" Routledge USA

Hutchinson T., (1987) "English for specific purpose" Kembridge University Press.

Corder N., (2008) "Learning to teach adults" Routledge

Harmer J., (2010) "How to teach English" Pearson Longman

Hutchinson T., \& Waters A, (1987), "English for specific purposes", Cambridge University Press

Tamo A, Rapti E, Karaj Th, (2005), "Mësimdhënia dhe të nxënit", Tiranë , Mokra,

Aliu I., (2004) "Metodologji e mësimnxënies", Tirane Pegi

Lynch T., (1996)" Communication in the language classroom", Oxford

Thomas S. Farrell C and George M. Jacobs (2010) "Essentials for Successful English Language Teaching" Continuum

Diller, K. C., (1971). "Generative Grammar, Structural Linguistics, and Language Teaching.: Newbury House Publishers

Coleman, A., (2012) "The Teaching of Modern Foreign Languages in the United States". Literary Licensing, LLC

Howatt, A. P. R., ( 198 4) "A History of English Language Teaching". Oxford University Press

Gauntlett J. O., (1957) "Teaching English as a Foreign Language". London: Macmillan

Palmer, H. E., (1968), "The Scientific Study and Teaching of Languages". London: Oxford University Press,

Thorne. K., (2003) "Blended Learning: How to Integrate Online and Traditional Learning" Great Britain Clays

Macdonald J., (2008) "Blended learning and online tutoring" England, Gower publishing

Palmer, H. E. (1934) "Specimens of English Construction Patterns". Department of Education

Billows, F. L. , (1961). "The Techniques of Language Teaching. London": Longman

]akobovits, L. A., ( 1970). "Foreign Language Learning: A Psycho linguistic Analysis of the Issues". Newbury House

Bentley T., (1998) "Learning beyond the classroom "Routledge Richard J and Rodgers Th., (2001) "Approaches and methods in language teaching" Cambridge University Press

Burton G., (1980) "Teaching English as a foreign language" New York Routledge 